\title{
Determinants of effective tax rates for firms listed on Chinese stock market: Panel models with two-sided censors
}

\author{
Yong-Ching Chiou ${ }^{\mathrm{a}}$, Yao-Chih Hsieh ${ }^{\mathrm{b}}$, Wenyi Lin ${ }^{\mathrm{c}}$ \\ a Department of Insurance and Finance, National Taichung University of Science and Technology, Taiwan. \\ b Department of Public Finance, Feng Chia University, Taiwan. E-mail: ychsieh@fcu.edu.tw \\ ${ }^{\mathrm{c}}$ Graduate Institute of Financial and Economic Law, Feng Chia University, Taiwan. E-mail: wylin@fcu.edu.tw \\ *Corresponding author's email address: yvonne@nutc.edu.tw
}

H I G H L I G H T S:

1. This paper highlights the role of tax preferences within set effective tax rates between 0 and 1 .

2. This paper attempts to use the panel models with two-sided censoring suggested by Alan, Honor'e, and Leth-Petersen (2014) to study the determinants of ETRs for the listed on China stock markets.

3. This article adopts four definitions of ETR and the empirical results demonstrate fruitful conclusions.

4. Our findings suggest this model can add more observations especially the observations with tax preferences

\begin{tabular}{|c|c|}
\hline Article History & ABSTRACT \\
\hline $\begin{array}{l}\text { Received: } 11-08-2014 \\
\text { Accepted: } 20-10-2014 \\
\text { Available online: } 23-10-2014 \\
\text { Keywords: } \\
\text { Effective tax rate; } \\
\text { Political power (cost) hypothesis; } \\
\text { Tax preference; } \\
\text { Two-sided censoring. }\end{array}$ & $\begin{array}{l}\text { This paper is to investigate the determinants effective tax rate for the firms listed on China's } \\
\text { stock markets. The panel data consists of } 481 \text { firms from } 2007 \text { to } 2009 \text { as our empirical } \\
\text { data. In order to illustrate a country's tax policies on firms' real tax burdens, the dependent } \\
\text { variable, ETR, is left-censored at } 0 \text { and right-censored at } 1 \text {, the estimation for panel data } \\
\text { model with two-sided censoring suggested by Alan, Honor'e, and Leth-Petersen (2014) is } \\
\text { implemented in this paper. There are two important findings are obtained: first, this model } \\
\text { can add more observations especially the observations with tax preferences. Second, } \\
\text { theories suggest that ETR reflects outcomes of tax preference and this paper is the first time } \\
\text { to consider the effective tax rates set between } 0 \text { and } 1 \text { and this range is more meaningful for } \\
\text { the ETRs. }\end{array}$ \\
\hline
\end{tabular}

JEL Classification:

C21; C52; H22; H25.

DOI: http://dx.doi.org/10.18533/jefs.v2i05.141

(C) 2014 The Authors. This is an open access article under the terms of the Creative Commons Attribution License 4.0, which allows use, distribution and reproduction in any medium, provided the original work is properly cited.

\subsection{Introduction}

Due to its convenience for measuring the tax burdens of corporate, effective tax rates (ETRs) have long been used by policy makers and interest groups in tax reform rebates, especially those related to corporate tax provisions. Success in the political process normally leads to future changes in effective tax rates. Tax preferences include all special exemptions from taxable income, deductions in excess of normal amounts, and deferrals of taxable income that enabled some individuals or corporations with substantial income to pay little or no tax while other taxpayers with less income have been required to pay a relative higher percentage of their income in taxes.

Empirically, studies on the relation between ETRs and firm size have produced conflicting results. Zimmerman (1983) observes a positive association between ETRs and firm size while Porcano (1986) observes a negative association. No association between ETRs and firm size is found in Stickney and McGee (1982) and Shevlin and Porter (1992). Subsequent studies have tried to reconcile the conflicting results by using modified proxies, period, time, 
term, data basis, and methodologies (e.g., Kern and Morris,1992; Wilkie and Limberg,1990; Holland, 1998; Kim and Limpaphayom, 1998; Derashid and Zhang, 2003). All studies are based on OLS model and firms with negative ETR are eliminated from the sample. Some previous articles, in order to correct the specification, panel data models have been used to overcome the problem of model mis-specification in studies on determinants of ETRs (e.g. Gupta and Newberry, 1997; Harris and Feeny, 2003; Liu and Cao, 2007). Besides, Gupta and Newberry (1997) suggest that because ETRs concerns firms with tax refunds, negative income and measurement issue, they constrained the ETR of their sample firms to lie between zero and one. This is the characteristic of censored sample. However, the censoring characteristic of ETRs is not considered in existing literature. The effective tax rate for the current empirical research and cannot fully explain the role of tax preferences. Because of tax incentives has led many companies and therefore not subject to tax, to remove these samples clearly unreasonable. Therefore, the effective tax rate of less than 0 is set to 0 will be able to comply with the real situation. Besides, Derashid (2003) point out the effective tax rate of a firm may be greater than one for a number of reasons. One reason is that, in the process of consolidation within a group of firms, subsidiaries/associated firms with net operating profit are combined with those subsidiaries/associated firms with net operating loss. Thus, this article will be an effective tax rate is set to 1 .

In our sample, there are more than $13 \%$ of firms with zero ETRs. It is well known that the regression estimators are biased and inconsistent if the existence of censoring in dependent variable is neglected. Therefore, this paper attempts to use the panel data models with two-sided censoring suggested by Alan, Honor'e, and Leth-Petersen (2014) to study the determinants of ETRs for the listed on China stock markets.

The remaining of this paper is organized as follows. Section 2 introduces the estimation of panel data models with two-sided censoring suggested by Honor'e and Leth-Petersen (2014). Empirical studies are investigated in section 3. Conclusions are presented in the last section.

\subsection{Panel data models with two-sided censoring}

Since the effective tax rates are between 0 and 1 with a significant number of observations on either of the limits. In panel data setting, the specific model is

$y_{\mathrm{it}}^{*}=x_{\mathrm{it}}^{\prime} \beta+\epsilon_{\mathrm{it}}$
$\mathrm{y}_{\mathrm{it}}=\left\{\begin{array}{c}\mathrm{a} \text { if } \mathrm{y}_{\mathrm{it}}^{*}<a \\ \mathrm{y}_{\mathrm{it}}^{*} \text { if } \mathrm{a} \leq \mathrm{y}_{\mathrm{it}}^{*} \leq \mathrm{b} \\ \mathrm{b} \text { if } \mathrm{y}_{\mathrm{it}}^{*}>b\end{array}\right.$

Where $\epsilon_{\mathrm{it}}$ is stationary conditional on $\left(\chi_{\mathrm{i} 1}, \ldots, \chi_{\mathrm{iT}}\right)$. The derivation of estimator for $\beta$ suggested by Alan, Honor'e, and Leth-Petersen (2014) is briefly summarized as follows. Define, for $\mathrm{a} \leq \mathrm{b}$,

$\operatorname{ma} \operatorname{mi}\{a, y, b\}=\left\{\begin{array}{l}\mathrm{a} \text { if } \mathrm{y}<a \\ \mathrm{y} \text { if } \mathrm{a} \leq \mathrm{y} \leq \mathrm{b} \\ \mathrm{b} \text { if } \mathrm{y}>b\end{array}\right.$

So Eq. (01) can be written as

$y_{i t}=\operatorname{mami}\left\{a, X_{i t}^{\prime} \beta+\epsilon_{i t}, b\right\}$

Consider an individual, i, in two-time periods, $t$ and $s$. The distribution of $\left(y_{i t}-X_{i t}^{\prime} \beta\right)$ will be the same as that of $\epsilon_{\mathrm{it}}$ except that the former is censored from below at a $-X_{i t}^{\prime} \beta$ and from above at $\left(b-X_{i t}^{\prime} \beta\right)$. The dotted line depicts the distribution of $\epsilon_{i t}$, while the solid line gives the distribution of $\mathrm{b}-\mathcal{X}_{\mathrm{it}}^{\prime} \beta$, which typically has point mass at a $-\chi_{i t}^{\prime} \beta$ and $b-X_{i t}^{\prime} \beta$ (illustrated by the fatter vertical lines). Since $x_{i t}^{\prime} \beta$ will typically differ from $x_{i s}^{\prime} \beta$, the distributions of $y_{i t}-$ $x_{i t}^{\prime} \beta$ and $y_{i s}-x_{i s}^{\prime} \beta$ (given $\left(x_{i t} x_{i s}\right)$ ) will differ even if $\left\{\epsilon_{i t}\right\}$ is stationary. However, it is clear that one could obtain identically distributed "residuals" by artificially censoring $y_{i t}-X_{i t}^{\prime} \beta$ and $y_{i t}-X_{i s}^{\prime} \beta$ from below at max $\left\{\mathrm{a}-\mathcal{X}_{i t}^{\prime} \beta\right.$, a $\left.x_{i s}^{\prime} \beta\right\}$ and from above at $\min \left\{b-x_{i t}^{\prime} \beta, b-x_{i s}^{\prime} \beta\right\}$. One can then form moment conditions from the fact that the difference in these "re-censored" residuals will be orthogonal to functions of $\left(x_{i t}, \chi_{i s}\right)$.

Also define functions $u_{1}\left(y_{i t},\right)$ and $u_{2}\left(y_{i s},\right)$ over the interval $-(\mathrm{b}-\mathrm{a})$ to $(\mathrm{b}-\mathrm{a})$ as follows

$$
\begin{aligned}
& \mathrm{u}_{1}\left(\mathrm{y}_{\mathrm{it}}, \mathrm{d}\right)=\left\{\begin{array}{l}
\max \left\{\mathrm{y}_{\mathrm{it}}-\mathrm{d}, \mathrm{a}\right\} \text { for } \mathrm{b}-\mathrm{a} \geq \mathrm{d} \geq 0 \\
\min \left\{\mathrm{y}_{\mathrm{it}}, \mathrm{b}+\mathrm{d}\right\} \text { for } 0 \geq \mathrm{d} \geq-(\mathrm{b}-\mathrm{a})
\end{array}\right. \\
& \text { and } \\
& \mathrm{u}_{2}\left(\mathrm{y}_{\mathrm{is}}, \mathrm{d}\right)=\left\{\begin{array}{l}
\max \left\{\mathrm{y}_{\mathrm{is}}, \mathrm{b}-\mathrm{d}\right\} \text { for } \mathrm{b}-\mathrm{a} \geq \mathrm{d} \geq 0 \\
\min \left\{\mathrm{y}_{\mathrm{is}}+\mathrm{d}, \mathrm{a}\right\} \text { for } 0 \geq \mathrm{d} \geq-(\mathrm{b}-\mathrm{a})
\end{array}\right.
\end{aligned}
$$

With these definitions, $u_{1}\left(y_{i t}, x_{i t}^{\prime} \beta-x_{i s}^{\prime} \beta\right)-u_{2}\left(y_{i s}, x_{i t}^{\prime} \beta-x_{i s}^{\prime} \beta\right)$ will give the difference in the re-censored residuals by artificially censoring $y_{i t}-X_{i t}^{\prime} \beta$ and $y_{i s}-X_{i s}^{\prime} \beta$ from below atmax $\left\{\mathrm{a}-\mathcal{X}_{i t}^{\prime} \beta, \mathrm{a}-\mathcal{X}_{i s}^{\prime} \beta\right\}$ and from above at min $\left\{b-X_{i t}^{\prime} \beta, b-\right.$ $\left.\chi_{i s}^{\prime} \beta\right\}$. 
Let the functions $r_{1}\left(y_{i t},.\right)$ and $r_{2}\left(y_{i s},.\right)$ are defined over the interval $-(\mathrm{b}-\mathrm{a})$ to $(\mathrm{b}-\mathrm{a})$ as

$$
r_{1}\left(y_{i t}, d\right)=\left\{\begin{array}{c}
d b+\frac{1}{2} d^{2}+\frac{1}{2}\left(y_{i t}-b\right)^{2} \text { for } d \leq y_{1}-b \\
d y_{i t} \text { for } y_{i t}-b \leq d \leq \mathrm{a} \\
d y_{i t}-\frac{1}{2} d^{2} \text { for } \mathrm{a} \leq d \leq y_{i t}-\mathrm{a} \\
d \mathrm{a}+\frac{1}{2}\left(y_{i t}-\mathrm{a}\right)^{2} \text { for } y_{i t}-\mathrm{a} \leq d
\end{array}\right.
$$

and

$$
r_{2}\left(y_{i s}, d\right)=\left\{\begin{array}{c}
d \mathrm{a}+\frac{1}{2} d^{2}+\frac{1}{2}\left(y_{i s}-\mathrm{a}\right)^{2} \text { for } d \leq-\left(y_{i s}-\mathrm{a}\right) \\
\frac{1}{2} d^{2}+d y_{i s} \text { for }-\left(y_{i s}-\mathrm{a}\right) \leq d \leq \mathrm{a} \\
d y_{i s} \text { for } 0 \leq d \leq b-y_{i s} \\
d b-\frac{1}{2} d^{2}-\frac{1}{2}\left(y_{i s}-b\right)^{2} \text { for } b-y_{i s} \leq d
\end{array}\right.
$$

The functions $r_{1}\left(y_{i t},.\right)$ and $r_{12}\left(y_{i s},.\right)$ are constructed, so their derivatives are $u_{1}\left(y_{i t},.\right)$ and $u_{2}\left(y_{i s},.\right)$, respectively. Finally, define

$$
R\left(y_{i t}, y_{i s}, d\right)=r_{1}\left(y_{i t}, d\right)-r_{2}\left(y_{i s}, d\right)
$$

Alan, Honor'e, and Leth-Petersen (2014) show that

$$
\frac{\partial}{\partial d} R\left(y_{i t}, y_{i s}, d\right)=r_{1}\left(y_{i t}, d\right)-r_{2}\left(y_{i s}, d\right)
$$

Suppose that

and

$$
\begin{aligned}
& y_{\text {it }}=\operatorname{mami}\left\{a, \delta+\epsilon_{i t}, b\right\} \\
& y_{\text {is }}=\operatorname{mami}\left\{a, \epsilon_{i s}, b\right\}
\end{aligned}
$$

Where $\epsilon_{\mathrm{it}}$ and $\epsilon_{\mathrm{is}}$ are identically distributed random variables with support on the whole real line. Then Alan, Honor'e and Leth-Petersen (2014) prove that

$\arg _{d \in[-(b-a),(b-a)]^{E}}\left[R\left(y_{i t}, y_{i s}, d\right)\right]=\left\{\begin{array}{c}-(b-a) \text { if } \delta \leq-(b-a) \\ \delta \text { if }-(b-a)<\delta<(b-a) \\ (b-a) \text { if } \delta \geq(b-a)\end{array}\right.$

If $\epsilon_{\mathrm{it}}$ is stationary conditional on $\left(X_{\mathrm{it}}, \chi_{\mathrm{is}}\right)$ with support on the whole real line, then the set of solutions to

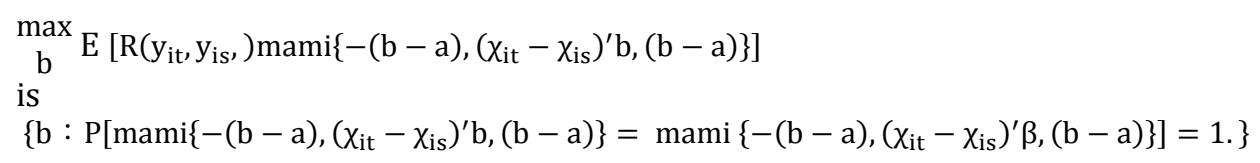

Therefore, when the censoring points are $a$ and $b$, the sample analog estimator is $\widehat{\beta_{n}}=\arg \max _{b} \sum_{i=1}^{n} \sum_{1 \leq s \leq t \leq T_{i}} w_{i, t-s} R\left[y_{i s}, y_{i t} \operatorname{mami}\left\{-(b-a), 1,\left(\chi_{i s}-\chi_{i t}\right)^{\prime} b,(b-a)\right\}\right]$

where the $\mathrm{w}_{\mathrm{i}, \mathrm{t}-\mathrm{s}}^{\prime} \mathrm{s}$ are exogenous weights and $\mathrm{T}_{\mathrm{i}}$ is the number of observations for the ith individual. $\mathrm{w}_{\mathrm{i}, \mathrm{t}-\mathrm{s}}=1 / \mathrm{T}_{\mathrm{i}}$ is a trivial choice.

It is proved by Alan, Honor'e and Leth-Petersen (2014) that $\widehat{\beta_{n}}$ is consistent and asymptotically normal under appropriately conditions. Under random sampling

$$
\sqrt{\mathrm{n}}\left(\widehat{\beta}_{\mathrm{n}}-\beta\right) \rightarrow_{\mathrm{d}} \mathrm{N}\left(0, \Gamma^{-1} \mathrm{~V}+\Gamma^{-1}\right)
$$

Where

$$
\begin{aligned}
& \Gamma=\mathrm{E}\left[\sum_{\mathrm{s}<t} \mathrm{w}_{\mathrm{i}, \mathrm{t}-\mathrm{s}} 1\left\{-(\mathrm{b}-\mathrm{a})<\left(\chi_{\mathrm{is}}-\chi_{\mathrm{it}}\right)^{\prime} \beta<(\mathrm{b}-\mathrm{a})\right\}\right. \\
& \left(1\left\{-(b-a)<\left(\chi_{i s}-\chi_{i t}\right)^{\prime} \beta<y_{i s}-b\right\}-1\left\{-(b-a)<\left(\chi_{i s}-\chi_{i t}\right)^{\prime} \beta<y_{i s}-a\right\}\right) \\
& -1\left\{\mathrm{a}-\mathrm{y}_{\mathrm{it}}<\left(\chi_{\mathrm{is}}-\chi_{\mathrm{it}}\right)^{\prime} \beta<\mathrm{a}\right\}+1\left\{\mathrm{~b}-\mathrm{y}_{\mathrm{it}}<\left(\chi_{\mathrm{is}}-\chi_{\mathrm{it}}\right)^{\prime} \beta<(\mathrm{b}-\mathrm{a})\right\}
\end{aligned}
$$

Following standard arguments, these are consistently estimated by

$$
\begin{aligned}
\widehat{\Gamma_{n}}= & \frac{1}{n} \sum_{\mathrm{i}=1}^{\mathrm{n}}\left[\sum_{\mathrm{s}<t} \mathrm{w}_{\mathrm{i}, \mathrm{t}-\mathrm{s}} 1\left\{-(\mathrm{b}-\mathrm{a})<\left(\chi_{\mathrm{is}}-\chi_{\mathrm{it}}\right)^{\prime} \widehat{\beta_{\mathrm{n}}}<(\mathrm{b}-\mathrm{a})\right\}\right. \\
& \left(1\left\{-(\mathrm{b}-\mathrm{a})<\left(\chi_{\mathrm{is}}-\chi_{\mathrm{it}}\right)^{\prime} \widehat{\beta_{\mathrm{n}}}<\mathrm{y}_{\mathrm{i}}-\mathrm{b}\right\}-1\left\{-(\mathrm{b}-\mathrm{a})<\left(\chi_{\mathrm{is}}-\chi_{\mathrm{it}}\right)^{\prime} \widehat{\beta_{\mathrm{n}}}<\mathrm{y}_{\mathrm{i}}-\mathrm{a}\right\}\right)
\end{aligned}
$$


and

$$
\begin{aligned}
& -1\left\{\mathrm{a}-\mathrm{y}_{\mathrm{it}}<\left(\chi_{\mathrm{is}}-\chi_{\mathrm{it}}\right)^{\prime} \widehat{\beta_{\mathrm{n}}}<a\right\}+1\left\{\mathrm{~b}-\mathrm{y}_{\mathrm{it}}<\left(\chi_{\mathrm{is}}-\chi_{\mathrm{it}}\right)^{\prime} \widehat{\mathrm{\beta}_{\mathrm{n}}}<(\mathrm{b}-\mathrm{a})\right\} \\
& \left.\left(\chi_{\mathrm{is}}-\chi_{\mathrm{it}}\right)\left(\chi_{\mathrm{is}}-\chi_{\mathrm{it}}\right)^{\prime}\right]
\end{aligned}
$$

$\widehat{\mathrm{V}_{\mathrm{n}}}=\frac{1}{\mathrm{n}} \sum-\mathrm{i}=1^{\mathrm{n}} \widehat{\mathrm{v}_{1}} \widehat{\mathrm{v}_{1}^{\prime}}$

With

$\widehat{v_{1}}=\frac{1}{T_{i}} \sum_{s<t} w_{i, t-s} 1\left\{-(b-a)<\left(\chi_{i s}-\chi_{i t}\right)^{\prime} \widehat{\beta_{n}}<(b-a)\right\}$

$\left(\mu_{1}\left(y_{\mathrm{is}},\left(\chi_{\mathrm{it}}-\chi_{\mathrm{is}}\right)^{\prime} \widehat{\beta_{\mathrm{n}}}\right)-\mu_{2}\left(\mathrm{y}_{\mathrm{it}},\left(\chi_{\mathrm{is}}-\chi_{\mathrm{it}}\right)^{\prime} \widehat{\beta_{\mathrm{n}}}\right)\right)\left(\chi_{\mathrm{is}}-\chi_{\mathrm{it}}\right)$.

\subsection{Empirical studies}

The sample data used in this study is collected from the Taiwan Economic Journal (TEJ) database. It consists of 481 firms each year listed on China's stock market from 2007 to 2009. The ETR is measured as four different ETRs measures are used. We follow the approach used by Porcano (1986), ETR1 is defined as (tax expenses - deferred tax expenses) divided by (profit before interest and tax paid) and ETR2 is another version of the measure used by Porcano (1986): (tax expenses)/ (profit before interest and tax). ETR 3 is a measure used by Stickney and McGee (1982) and is given as (tax expenses)/ (pre-tax profit- (deferred tax expenses/statutory tax rate)). ETR4 is the measure used by Shevlin (1987) and is calculated as (tax expenses-deferred tax expenses)/ (pre-tax profit (changes in deferred tax/statutory tax rate)). Whenever firms report, negative income is eliminated from the sample. Negative numerator (tax refunds) will be included in the sample because of considering tax preferences. It is worthy to mention that the negative ETRs are replaced with zeros and one for those larger than one. There are, totally, 72, 101, 114 and 86 firms with zero ETR for definitions of ETR1, ETR2, ETR3 and ETR4. For the right censoring, there are 0, 0,16 and eight firms with ETR equal to one in ETR1, ETR2, ETR3, and ETR4, respectively.

To explore the marginal effect of firm size on ETRs, the following firm-specific characteristics are taken as control variables: leverage (total liabilities divided by total asset value, denoted as "LEV"), capital intensity (net fixed assets divided by total assets, denoted as " $\mathrm{CI}^{\prime}$ ), inventory intensity (inventory divided by total assets, denoted as "II"), and return on assets (pre-tax profits divided by total assets, denoted as "ROA"), firm size (denoted as "SIZE") is measured as the natural logarithm of total asset value. The state ownership variable is defined as the ratio of state-owned shares over total outstanding shares and denoted as S1. The reasons behind to choose these variables are based on previous studies (e.g., Porcano (1986), Gupta and Newberry (1997), Derashid and Zhang (2003), Liu and Cao (2007)). To account for the factors discussed above, the empirical results are presented in table 01.

The coefficients for S1, government equity, do not appear to be statistically different from zero, except ETR2. These results suggest that the effects of government ownership may draw different conclusions because of the definitions of ETR. The coefficients for capital intensity are all statistically insignificant for all ETR measures. These evidences do not support the notion that higher capital investment and the resultant higher depreciable costs lead to a lower ETR. The coefficient for inventory intensity, on the other hand, is statistically different from zero under all ETR measures. The coefficient for leverage is negative and statistically significant when ETR is measured as ETR1. The coefficients are not statistically different from zero under ETR2, ETR3, and ETR4. Thus, there are evidences to support the intuitive notion that debt financing can be used as a tax shield for China's firms. The coefficients for inventory intensity are all statistically different from zero under all ETR measures. The coefficients of ROA, the measure for efficiency in performance, are all positive significant when ETR is measured as ETR1, ETR2, ETR3, ETR4. These results suggest that more efficient firms pay more effective tax in China. Moreover, these results are consistent to previous studies. The coefficients for firm size are positive and statistically significant when ETR is measured as ETR1, ETR3, and ETR4. Thus, we can accept the political cost hypothesis when ETR is defined as ETR1, ETR3, and ETR4. Finally, all the coefficients of year dummies for each of the four ETR measures are negative and statistically significant.

\begin{tabular}{lcccc}
\hline \multicolumn{5}{c}{ Table 01: Estimated results for panel data model with two-side censoring } \\
\hline$\alpha$ & ETR1 & ETR2 & ETR3 & ETR4 \\
\hline \multirow{4}{*}{ S1 } & -0.045 & $0.091^{*}$ & 0.026 & -0.001 \\
& $(0.052)$ & $(0.050)$ & $(0.073)$ & $(0.060)$ \\
CI & -0.005 & $0.029^{*}$ & 0.038 & -0.001 \\
& $(0.016)$ & $(0.015)$ & $(0.024)$ & $(0.019)$ \\
II & -0.013 & -0.004 & 0.030 & 0.021 \\
& $(0.025)$ & $(0.024)$ & $(0.036)$ & $(0.029)$ \\
LEV & $0.105^{* * *}$ & $0.096^{* * *}$ & $0.111^{* *}$ & $0.153^{* * *}$ \\
& $(0.033)$ & $(0.032)$ & $(0.048)$ & $(0.039)$ \\
ROA & $-0.137^{* * *}$ & -0.055 & -0.024 & -0.059 \\
& $(0.043)$ & $(0.040)$ & $(0.064)$ & $(0.051)$ \\
& $0.127^{* * *}$ & $0.192^{* * *}$ & $0.209^{* * *}$ & $0.144^{* * *}$ \\
\hline
\end{tabular}




\begin{tabular}{lcccc}
\hline \multirow{2}{*}{ SIZE } & $0.013^{* * *}$ & 0.002 & $0.009^{*}$ & $0.011^{* * *}$ \\
& $(0.004)$ & $(0.003)$ & $(0.005)$ & $(0.004)$ \\
Y2008 & $-0.013^{* *}$ & $-0.029^{* * *}$ & $-0.054^{* * *}$ & $-0.031^{* * *}$ \\
& $(0.006)$ & $(0.006)$ & $(0.010)$ & $(0.007)$ \\
Y2009 & $-0.028^{* * *}$ & $-0.022^{* * *}$ & $-0.017^{*}$ & $-0.028^{* * *}$ \\
& $(0.007)$ & $(0.006)$ & $(0.011)$ & $(0.008)$
\end{tabular}

\subsection{Conclusions}

To demonstrate a national real tax preferences policy, ETRs concerns firms with a tax refund, negative income and measurement issue, not like previous research; this paper adopts two-sided censoring model to investigate the determinants of ETRs for the firms listed on China's stock markets. Since the dependent variable, ETRs, is leftcensored at zero and right-censored at 1, the estimation for panel data model with two-sided censoring suggested by Honor'e and Leth-Petersen (2014) is implemented in this paper. Several contributions are obtained: first, this model can add more observations especially the observations with tax preferences which are the essence of a country's tax policies. Second, at our best knowledge, this paper is the first time to consider the effective tax rates set between 0 and 1 and this range is more meaningful for the ETRs. Third, for a comparison with previous research, this article adopts four definitions of ETR and the empirical results demonstrate fruitful conclusions.

\section{References}

Alan, S., and S. Leth-Petersen, 2006. Tax incentives and household portfolios: A panel data analysis. Center for Applied Microeconometrics, University of Copenhagen, Working paper number 2006-13.

Alan, S., Bo E. Honor'e, and S. Leth-Petersen, 2014. Estimation of panel data models with two-sided censoring or truncation. Journal of Econometric Methods, 3(1): 1-20. http://dx.doi.org/10.1515/jem-2012-0012

Callihan, D.S., 1994. Corporate effective tax rates: A synthesis of the literature. Journal of Accounting Literature, 13(1): $1-43$.

Derashid, Check, and Hao Zhang, 2003. Effective tax rates and the industrial policy hypothesis: evidence from Malaysia. Journal of International Accounting Auditing and Taxation, 12(1): 45-62. http://dx.doi.org/10.1016/S1061-9518(03)00003-X

Gupta, S., and K. Newberry, 1997. Determinants of the variability of corporate effective tax rates: evidence from longitudinal Data. Journal of Accounting and Public Policy, 16(1): 1-34. http://dx.doi.org/10.1016/S02784254(96)00055-5

Harris, M. N. and S. Feeny, 2003. Habit persistence in effect tax rates. Applied Economics, 35(8): 951-958. http://dx.doi.org/10.1080/0003684032000050577

Holland, K., 1998. Accounting policy choice: The relationship between corporate tax burdens and company Size. Journal of Business Finance and Accounting, 25(3-4): 265-288. http://dx.doi.org/10.1111/1468-5957.00187

Kim, K.A., and P. Limpaphayom, 1998. Tax and firm size in Pacific-Basin emerging economies. Journal of International Accounting Auditing and Taxation, 7(1): 47-63. http://dx.doi.org/10.1016/S1061-9518(98)90005-2

Kern, B. B. and M. H. Morris, 1992. Taxes and firm Size: The effect of tax legislation during the 1980s. Journal of the American Taxation Association, 14(1): 80-96.

Liu, Xing and Shujun Cao, 2007. Determinants of corporate effective tax rates: evidence from listed companies in china. The Chinese Economy, 40(6): 49-67. http://dx.doi.org/10.2753/CES1097-1475400603

Porcano, T., 1986. Corporate Tax Rates: Progressive, proportional, or regressive. Journal of the American Taxation Association, 7(2): 17-31.

Powell, J.L., 1984. Least absolute deviations estimation for the censored regression model. Journal of Econometrics, 25(3): 303-325. http://dx.doi.org/10.1016/0304-4076(84)90004-6

Powell, J.L., 1986. Censored regression quintiles. Journal of Econometrics, 32(1): $143-155$. http://dx.doi.org/10.1016/0304-4076(86)90016-3

Shevlin, T., 1987. Taxes and off-balance-sheet financing: research and development limited partnership. The Accounting Review, 62(3):480-509.

Shelvin, T., and S. Porter, 1992. The Corporate tax comeback in 1987: Some further evidence. Journal of American Taxation Association, 14(1): 58-79.

Stickney, C., and V. McGee, 1982. Effective corporate tax rates: The effect of size, capital intensity, leverage, and other factors. Journal of accounting and public policy, 1(2): 125-52. http://dx.doi.org/10.1016/S02784254(82)80004-5

Wilkie, P., 1988. Corporate average effective tax rates and inferences about the relative tax preference. Journal of the American Taxation Association, 10(1): 75-88.

Wilkie, P.J., and S.T. Limberg, 1990. The relationship between firm size and effective tax rate: A reconciliation of Zimmerman (1983) and Porcano (1986). Journal of American Taxation Association, 11(2): 76-91.

Zimmerman, J., 1983. Tax and firm size. Journal of Accounting and Economics, 5(2):119-149. http://dx.doi.org/10.1016/0165-4101(83)90008-3 